CEPAL REVIEW 88 A APIL 2006

\title{
Changes in Chile's production structure, 1986-1996: Output and industrial interdependence
}

\author{
José Miguel Albala-Bertrand
}

I

n earlier studies, the author showed that the type of development adopted by Chile differed significantly from that of the successful East Asian countries. Up to 1986 , the Chilean economy had a relatively weak and technologically unsophisticated manufacturing base, and the penetration of imported inputs was mainly at the expense of the scanty domestic productive intermediation. Therefore, neither manufacturing industrialization nor industrial interdependence appeared to facilitate the type of manufactured exports that might sustain dynamic industrial development based on external markets. The present paper analyses changes in Chile's production structure from 1986 to 1996, generally extended to 2000, using methods similar to those of earlier studies. The conclusion is that, despite the outstanding growth rates over the period, the economy still appears relatively weak as a basis for a sustainable increase in economic and technological sophistication.

José Miguel Albala-Bertrand Department of Economics, Queen Mary, University of London 


\section{I}

\section{Introduction}

This study continues previous work by the author on the changes in both production structures and industrial interdependence in Chile between 1960 and 1990 (Albala-Bertrand, 1999a and 1999b). The results were then contrasted with those of some newly industrializing countries at comparable stages of development, with the aim of assessing to what extent policies based upon the Washington Consensus would produce economic structures which were generally as successful as those of countries that had applied the Japanese/Asian model.

In short, in the last few decades, two main competing market-oriented policy models for development have arisen: the Japanese/Asian model and the Washington Consensus model. Both stress the importance of macroeconomic stability, export-led development and private enterprise. They differ fundamentally, however, as regards the development roles of the market and the State, and consequently the range and types of economic policies available (Wade, 1990; Stiglitz, 1996; Chang and Grabel, 2004).

The main emphasis of the Washington Consensus model is to ensure the liberalization of trade through the removal of most if not all trade barriers and to achieve macroeconomic stability via balanced budgets and privatization and through deregulation and liberalization in order to allow price signals to operate efficiently in the economy (Williamson, 1990). The State is to be reduced to a minimal and subsidiary role. Economic policies, therefore, are to be neutral and operate automatically through the market. The extreme version of this model postulates that market failures are always less costly than government intervention and failure, so government is irrelevant in most, if not all, cases (Krueger, 1990).

The Japanese/Asian Model, on the other hand, while expressly recognizing the importance of macroeconomic stability and export orientation, has some misgivings about the "free market" mechanism. It considers that the State should have a fundamental and pivotal role in the direction and speed of development, especially -but not exclusively- as regards industrial policy. This means that selective (not neutral) and regulatory (not automatic) policies are essential for achieving dynamic (as opposed to static) and strategic (as opposed to blind) development. Among other functions, the government should contribute to the creation of dynamic comparative advantages via enlightened protectionism, for the benefit of potential export winners, and to the coordination of the economy as a whole. ${ }^{1}$ Even if it were not directly involved in production activities, the State would therefore provide a fundamental input in guiding and streamlining changes in production structures.

In comparing the two policy models, in his earlier works the author chose to examine the economies in which they had been applied most successfully: Chile in the case of the Washington Consensus model, and the Taiwanese economy and the Republic of Korea for the Japanese/Asian model. It was shown that in Chile, contrary to the situation in the East Asian countries, and whatever other successes the Chilean experiment may have shown, both industrial interdependence and industrialization based on exports of manufactures were still weak and unpromising as endogenous bases capable of sustaining dynamic industrial development led by external markets (Albala-Bertrand, 1999a and 1999b). As late as 1990 , at least 15 years after the beginning of this experiment in Chile, and even allowing for the differences in initial conditions, Chile's economy and production structure significantly differed from those of the Republic of Korea and the Taiwanese economy.

The present paper seeks to assess whether there was any convergence between the respective situations over the period 1986-1996, which in growth terms was the most successful ever in Chilean economic history, with annual growth rates averaging 7\%. After 1986, however, there seems to have been little in the way of industrial policy in Chile, and the government generally favoured the prevailing Washington Consensus policies. This does not mean that the government did not make an important contribution to the formulation or correction of policy packages to derive greater benefit from the strategy being used,

\footnotetext{
${ }^{1}$ See Wade (1990); Chang (1996); Stiglitz (1996 and 1998); Stiglitz and Uy (1996); Lall (1996 and 1997); Islam and Choudhury (2000), and Chang and Grabel (2004).
} 
nor does it mean that there was no public policy aimed at nurturing certain basic manufacturing industries. ${ }^{2}$ It does, however, mean that those strategies were neither systematic nor all-embracing and that they did not favour the type of industrial policy associated with the successes of the Republic of Korea and the Taiwanese economy: i.e., the Japanese/Asian model. To this end, this paper therefore analyses input-output data for 19861996 , generally updating its results to $2000 .^{3}$

To avoid any misunderstandings, it seems desirable to clarify the type of structural change that can be analysed using the methodology described below. Changes in production structures -the central focus of this paper- may result from institutional changes or from growth differentials between sectors in a given institutional framework. Chile experienced massive

\section{II}

\section{Methodology}

Chenery (1960) was the first to put forward a methodology to assess changes in the structure of gross output. This methodology was based on input-output tables and was later refined by several authors. ${ }^{5}$ The decomposition method actually used in this paper is closer to that of Wyckoff and Sakurai (1992) and AlbalaBertrand (1999a). This method of analyzing changes in production structure capitalizes on most of the advantages of the input-output approach, while avoiding most of its limitations: that is, it reduces the importance of its usual shortcomings for forecasting (Bulmer-Thomas 1982; Ciaschini, 1988).

One advantage, fully exploited here, is that the overall structural change over a given period can be decomposed into the sources of demand which contribute to the change, both for the industrial complex as a whole and for each constituent industry. The sources of demand, however, should not be taken as explaining structural change in terms of causality but only in terms of ex-post concomitance. These are therefore useful empirical foundations for a structurally

${ }^{2}$ See Achurra (1995); Agosin (1997); Moguillansky (1999) and Ffrench-Davis and Stalling (2001).

${ }^{3}$ For more details, see Albala-Bertrand (1999a and 1999b).

${ }^{4}$ See Albala-Bertrand (1996).

${ }^{5}$ See, for example, Dervis, de Melo and Robinson (1982); Kubo, de Melo and others (1986); Sakurai (1990). institutional changes between 1975 and 1985, and from 1986 to 1996 it underwent further important changes, but in more balanced and moderate ways than in the previous 10 years. The resulting variations in the composition of gross output, as described in this paper, relate to the latter period, during which the institutional framework of the earlier period was mostly retained. The variations are therefore likely to have a considerable institutional component, resulting from both the overall strategy followed since 1975 and the policy changes adopted during the period 1986-1996. ${ }^{4}$ Thus, the method used captures some sectoral and intersectoral changes in the Chilean economy in that period, in the framework of the prevailing institutions and policy strategies that may have affected economic variables such as growth and productivity. comprehensive policy analysis, which would exceed the scope of this paper.

In turn, the method used in evaluating structural changes in industrial interdependence -understood as structural change in internal interactions among industries at the level of intermediate goods- is based on multiplier analysis applied to backward and forward linkages. The main difference between our analysis and standard linkage analysis is that, in input-output theory, the standard analysis adopts an ex-ante approach to the potential for planning economic expansion (Hirschman, 1958 and 1977; Syrquin, 1992). In our analysis, however, since our purpose is to analyse effective changes in structural linkages over time, the linkages represent the actual or ex-post interdependence of the economy in 1986 and 1996. This also greatly reduces the restrictiveness of the assumptions required for standard analysis. ${ }^{6}$

Consequently, starting from the standard general input-output framework, we can arrive at some useful equations for the purpose of analysing changes in production structure as well as industrial interdependence. ${ }^{7}$ In matrix form, for structural change

\footnotetext{
${ }^{6}$ See also Albala-Bertrand (1999b).

${ }^{7}$ For a full presentation of these models see Albala-Bertrand (1999a and 1999b).
} 
we initially use an equation for variations in gross output, as:

$$
\begin{aligned}
\Delta X & =B_{0} \hat{U}_{o}{ }^{F} \Delta F+B_{0} \Delta E+B_{0} \Delta \hat{U}^{F} F_{1} \\
& +B_{0} \Delta \hat{U}^{W} W_{1} i+B_{0} \hat{U}_{0}{ }^{W} \Delta A X_{1}
\end{aligned}
$$

where $\Delta X$ is the variation of gross output, $B$ is an adapted Leontief inverse, $U$ represents the proportion of domestic intermediates to total intermediates (superindex $W$ ) and domestic final demand to total final demand (superindex $F$ ), $F$ is final demand, $E$ is foreign demand and $W$ is intermediate demand. The subindices "0" and "1" represent the initial and final years (1986 and 1996) respectively. The decomposition of the gross output growth rate can be obtained by dividing the equation [1] by $X_{0}$. Each of the five terms on the righthand side of [1], in variation or growth terms, represents a direct and indirect contribution to total demand for the gross output of the economy, and has the following standard meanings:

$$
\begin{aligned}
B_{0} \hat{U}_{0}^{F} \Delta F= & \begin{array}{l}
\text { contribution of final domestic demand } \\
\text { expansion (FDE); }
\end{array} \\
B_{0} \Delta E & =\begin{array}{l}
\text { contribution of export demand } \\
\text { expansion (EDE); }
\end{array} \\
B_{0} \Delta \hat{U}^{F} F_{1}= & \begin{array}{l}
\text { contribution of import substitution of } \\
\text { final goods (ISF) } ;
\end{array} \\
B_{0} \Delta \hat{U}^{W} W_{1} i= & \begin{array}{l}
\text { contribution of import substitution of } \\
\text { intermediate goods (ISW); }
\end{array} \\
B_{0} \hat{U}_{0}^{W} \Delta A X_{1}= & \begin{array}{l}
\text { contribution of changes in direct input- } \\
\text { output coefficients (IOC). }{ }^{9}
\end{array}
\end{aligned}
$$

We then use the following equation for variations in the share of gross output, as:

$$
\begin{aligned}
\delta X & =B_{0} \hat{U}_{o}{ }^{F} \delta F+B_{0} \delta E+B_{0} \Delta \hat{U}^{F} F_{1} \\
& +B_{0} \Delta \hat{U}^{W} W_{1} i+B_{0} \hat{U}_{0}{ }^{W} \Delta A X_{1}
\end{aligned}
$$

\footnotetext{
${ }^{8}$ Terms 3 and 4 are positive when there has been an increase in import substitution over the period. Conversely, a decrease in import substitution means an increase in import penetration. ${ }^{9}$ This represents the variation in demand over the period, exclusively as a result of variations in the input-output coefficients of the system, weighted by the average of $X_{1}$. If this term is positive for a particular industry, then this means that a greater proportion of the output of that industry is used as input for the production of other industries than in the base year. That is, it represents an increase in the contribution to direct intermediation by that industry with regard to the economy. As such, it represents a version of direct backward linkages (demand) from the rest of the economy to that industry, or alternatively a version of the direct forward linkage (supply) from that industry to the rest of the economy over the period (Hirschman, 1977).
}

where all the terms have the same meaning as above, but $\delta$ represents the deviation from balanced growth (that which would have prevailed if all sectors had grown at the same mean growth rate as the economy). This is therefore an indication of structural change through sectoral share changes over the period. The last three terms on the right-hand side are the same as before. The meaning is analogous to that of equation [1], but refers to the absolute value of the share change $(\delta X)$ and the relative share change $\left(\delta X / X_{t 1}\right)$, rather than absolute growth $(\Delta X)$ and the growth rate $\left(X^{-1} \Delta X\right)$.

To analyse industrial interdependence, we calculate backward and forward linkages. We define the backward linkage $(B L)$ as the direct and indirect dependence of a particular industry on all industries, as they supply intermediate inputs for its own production. Dynamic industries are expected to increase their backward linkages, becoming more specialized as they develop, either because they need a greater quantity of a more varied input mix or because they have ceased in-house production of part of those inputs. Leading industries with strong vertical integration are therefore expected to exert a pull on the economy and, if they are technologically advanced, increase the technological sophistication of the overall economy. In matrix notation, backward linkages $(B L)$ are expressed as:

$$
B L=i^{\prime} C^{-1} \text { (backward linkage, row vector) }
$$

where $C^{-1}$ is a Leontief inverse. Theoretically, dynamic leading industries are expected to exhibit aboveaverage linkages and more equal distribution than other industries.

Finally, to assess how the backward linkages change over time, we simply calculate the first difference of their values between any two given years. However, as the matrix $C$ contains both domestic and imported intermediates, a decomposition is necessary to discriminate between the two. Thus:

$$
\begin{gathered}
\Delta B L=i^{\prime} \Delta C^{-1}=i^{\prime}\left(C_{0}^{-1} \Delta A^{d} C_{1}^{-1}\right) \\
+i^{\prime}\left(C_{0}^{-1} \Delta A^{m} C_{1}^{-1}\right)(\Delta B L \text { decomposition })
\end{gathered}
$$

where $A$ is a standard matrix of input coefficients. The superindices $d$ and $m$ stand for "domestic" and "imported," respectively. Equation [4] is a row vector of backward linkage differences between two years, " 0 " and " 1 ", decomposed into domestic and imported contributions. This can be more usefully presented in terms of growth rates (or rates of change) by dividing 
equation [4] by the value of $B L$ for the initial year, as shown in table 1 below.

Analogously to backward linkages, we define forward linkages $(F L)$ as the direct and indirect dependence that all industries have on a particular industry, because they require intermediate inputs from it for their own production. Given that there is no reason why $B L$ and $F L$ should be similar, we have to calculate the value of $F L$ to obtain a more complete picture of overall intermediate transactions. The procedure for doing this is fully analogous to that for $B L$. Then, in matrix notation, forward linkages $(F L)$ are expressed as follows:

$$
F L=C^{*-1} i \text { (forward linkage column vector) }
$$

where $C^{*-1}$ is a Leontief inverse of direct and indirect input supply (rather than demand) coefficients. Again, we expect the leading industries to exhibit more evenly distributed above-average linkages than other industries.

Lastly, the decomposition of the first difference of [5] yields the following $\triangle F L$ decomposition:

$$
\begin{aligned}
\Delta F L= & \left(\Delta C^{*-1}\right) i=\left(C^{*}{ }_{0}^{-1} \Delta A^{* d} C_{1}^{*-1}\right) i \\
& +\left(C^{*}{ }_{1}^{-1} \Delta A^{* m} C^{*}{ }_{1}^{-1}\right) i
\end{aligned}
$$

where $A^{*}$ is a matrix of direct input-supply coefficients and the superindices $d$ and $m$ stand for "domestic" and "imported," respectively. This equation is a column vector of forward linkage differences between two years, "0" and " 1 ", decomposed into domestic and imported contributions. As in the previous case, this can also be more usefully presented in terms of growth rates (or rates of change) by dividing equation [6] by the value of $F L$ for the initial year.

\section{III}

\section{Analysis of results}

For this purpose, we used a 28-industry disaggregation, plus some relevant subgroups. The analysis focuses on the period 1986-1996, generally contrasting it with the earlier period 1977-1986 analysed previously by the same author (Albala-Bertrand, 1999a and 1999b). The latter period is used only as a general reference of trends, as in these earlier studies the results were calculated with user prices rather than basic prices, since the latter were not shown in the original 1977 inputoutput tables. ${ }^{10}$ The present analysis is divided into two main parts: structural change in gross output and structural change in industrial interdependence.

\section{Structural change in gross output}

Table 1 below shows the change both in the share of industries or services in gross production, and the

\footnotetext{
${ }^{10}$ We used the 1986 and 1996 input-output tables. The 1996 table, which is the latest available for Chile, was published in 2001 and made available on the Internet in 2002. These tables were deflated at sectoral levels, where possible, differentiating between intermediates, value added, final output and total gross output, at constant 1986 prices. To this end, we used implicit deflators from the national accounts.
}

growth rates for those activities, for the period 19861996. We begin with the three major productive sectors: the primary or natural resources sector, the secondary or manufacturing sector (which includes construction in the table), and the tertiary (services) sector.

\section{a) Aggregated analysis}

In the three major sectors - primary, secondary and tertiary - the degree of structural change in gross output between 1986 and 1996 was similar to that for the previous decade, but growth rates were significantly higher. The fall in the share of the primary sector, which had halted in 1977-1986, resumed during 1986-1996, with a loss of a further 3.1 percentage points. As a result, the primary sector represented $16.3 \%$ of total gross output in 1996. In the case of the secondary sector, the significant increase in 1977-1986 was partly offset, with a fall of 2.8 percentage points, so that it made up $35.9 \%$ of gross output in 1996. The opposite appears to have happened with the tertiary sector: the significant fall in its share in 1977-1986 was reversed, with an increase of 5.9 percentage points, and it represented $47.8 \%$ of total gross output in 1996. All three sectors showed exceptionally high growth rates 
over this period, especially the tertiary sector, which appeared to have lagged well behind the other two sectors during the 1977-1986 period.

For the economy as a whole, the only demand component that seems to have contributed positively to the changes in the participation of the different sectors over 1986-1996 was a significant improvement in direct intermediation, represented by the inputoutput coefficients (IOC). This means that input demand for the output of all sectors, especially the secondary and tertiary sectors, made a positive contribution to both the growth rates and the shares of those sectors in the economy. All the other factors show negative contributions to shares of output, especially final demand expansion (FDE), import substitution of final goods (ISF) and import substitution of intermediate goods (ISW). Even export demand expansion -the most important positive contributor in 1977-1986- now showed a negative contribution. Domestic demand and exports, and to a lesser extent intermediation, appear to have made the greatest contributions to the high average growth rate (see table 1). Only import substitution held back the average growth rate, but in a small way. These aggregated results, however, hide the heterogeneous nature of structural change, so that we will now turn to a disaggregated analysis.

\section{b) Disaggregated analysis}

At this level of disaggregation, we will examine productive activities in the natural resources, manufacturing or services sectors.

i) The primary or natural resources sector (table 1 , lines 1 to 4 ). For 1986-1996, in contrast to the previous period, the shares fell for all constituent industries, especially for the non-mining primary sector, but remained virtually unchanged for copper. All industries, especially copper, showed significant increases in the growth rates of gross output, except for the fuel industries, which showed a $61 \%$ fall. All industries, however, grew at rates lower than the average for the economy, which explains their losses in terms of shares of output. The still-significant growth rates appear to have responded especially to final demand expansion (FDE) in the non-mining primary sector and to export demand expansion (EDE) in mining. The output fall in the case of fuels seems to have been mainly caused by massive falls in import substitution, especially of intermediate goods (ISW). The high growth rates of copper and other minerals, as expected, were mostly pulled by export demand, while the contribution from intermediation was almost nil, meaning that mining in Chile may have become more of an enclave industry than before. Contrary to the previous (1977-1986) period, the non-mining primary sector had a reasonably high growth rate contribution from intermediation, which may mean that these industries were better integrated in the overall economy than before.

To sum up, the copper industry retained a share in gross output similar to that in 1986 , but with a significantly higher growth rate, probably because of significant support from policy measures over the period. In 1996, its share in total output was over $6 \%$, which was good news for both overall growth and foreign exchange generation. Second, the average growth rate in the non-mining primary sector was practically double that for the period 1977-1986. Domestic demand and exports, as well as intermediation, played an important role in this recovery. Third, intermediation improved for the nonmining primary sector and consequently for fuels, while it worsened somewhat for copper and other minerals. While agriculture and associated industries appear to have become more integrated into the overall economy, extractive industries moved somewhat in the opposite direction, or lagged behind.

In terms of gross domestic product (GDP), mining increased its share between 1996 and 2000, while the non-mining primary industry (except for fishing) fell significantly; as a result, the participation of the overall primary sector was about the same in 2000 as in 1996 (Banco Central de Chile, various years). The primary sector as a whole was therefore growing at a similar rate to that of the economy as a whole, but with some internal structural changes. GDP relates only to the final demand component of gross output, but unlike gross output it is calculated at market rather than basic prices, including transport costs, wholesale margins and net indirect taxation. Hence, the growth rate and structure of GDP may provide a general picture of the behaviour of gross output over the same period, but this will not be confirmed until updated input-output tables are made available by the Central Bank.

ii) The secondary or manufacturing sector (table 1, lines 5 to 19). During the 1977-1986 period, the manufacturing sector increased its share of total gross output, but only because of light industries, since heavy industry -the most technologically advanced part of the secondary sector- saw a decline in its share. Both fell, however, during the 1986-1996 period: light industry by 3.2 percentage points and heavy industry by 1.5 points. For light industry, the main source of 
Chile: Growth rates and changes in the share of gross output, by production activity and sector, between 1986 and $1996{ }^{a}$

(Basic prices in constant 1986 pesos)

\begin{tabular}{|c|c|c|c|c|c|c|c|c|c|c|c|c|c|c|}
\hline \multirow{2}{*}{\multicolumn{2}{|c|}{ Production activity and sector }} & \multicolumn{7}{|c|}{ Share $\delta=(1996-1986)$} & \multicolumn{6}{|c|}{ Growth rate: $\Delta=(1996-1986)$} \\
\hline & & \multirow{2}{*}{\begin{tabular}{|r}
$\delta \mathrm{X} / \mathrm{X} 96$ \\
-1.6
\end{tabular}} & \multirow{2}{*}{$\begin{array}{r}\text { FDE } \\
-1.6\end{array}$} & \multirow{2}{*}{$\begin{array}{c}\text { EDE } \\
-0.6\end{array}$} & \multirow{2}{*}{$\begin{array}{c}\text { ISF } \\
-0.1\end{array}$} & \multirow{2}{*}{$\frac{\text { ISW }}{-0.4}$} & \multirow{2}{*}{$\frac{\mathrm{IOC}}{1.0}$} & \multirow{2}{*}{$\begin{array}{c}\text { S86 } \\
7.8\end{array}$} & \multirow{2}{*}{$\begin{array}{r}\Delta \mathrm{X} / \mathrm{X} 86 \\
75\end{array}$} & \multirow{2}{*}{$\begin{array}{r}\text { FDE } \\
40\end{array}$} & \multirow{2}{*}{$\begin{array}{r}\text { EDE } \\
26\end{array}$} & \multirow{2}{*}{$\begin{array}{r}\text { ISF } \\
-2\end{array}$} & \multirow{2}{*}{$\begin{array}{r}\text { ISW } \\
-8\end{array}$} & \multirow{2}{*}{$\frac{10 C}{19}$} \\
\hline 1 & Non-mining primary & & & & & & & & & & & & & \\
\hline 2 & Copper & -0.1 & 0.1 & -0.1 & 0.0 & 0.0 & 0.0 & 6.5 & 117 & 9 & 110 & -1 & 0 & -1 \\
\hline 3 & Fuels & -1.0 & -0.1 & 0.0 & -0.1 & -0.9 & 0.1 & 1.2 & -61 & 38 & 19 & -21 & -107 & 10 \\
\hline 4 & Other minerals & -0.3 & 0.1 & -0.3 & 0.0 & 0.0 & -0.1 & 3.9 & 103 & 20 & 88 & -1 & 0 & -3 \\
\hline 5 & Food & -3.3 & -3.4 & -0.5 & -0.2 & -0.3 & 1.0 & 10.5 & 52 & 25 & 19 & -3 & -4 & 14 \\
\hline 6 & Textiles & -0.9 & -0.6 & 0.1 & -0.3 & -0.1 & 0.1 & 1.5 & -13 & 3 & 17 & -24 & -14 & 6 \\
\hline 7 & Clothing & 0.0 & -0.3 & 0.1 & -0.2 & -0.1 & 0.5 & 1.6 & 127 & 81 & 19 & -17 & -6 & 50 \\
\hline 8 & Lumber/wood & -0.2 & -0.1 & -0.2 & 0.0 & 0.0 & 0.2 & 2.6 & 101 & 48 & 49 & -2 & -3 & 9 \\
\hline 9 & Paper/printing & 0.2 & -0.2 & 0.0 & -0.1 & 0.0 & 0.5 & 1.0 & 167 & 72 & 32 & -7 & -4 & 76 \\
\hline 10 & Leather & 1.1 & 0.4 & 0.1 & 0.0 & 0.0 & 0.6 & 0.5 & 648 & 366 & 76 & 8 & -6 & 203 \\
\hline 11 & Rubber & -0.2 & -0.2 & 0.0 & -0.1 & 0.0 & 0.1 & 0.6 & 37 & 14 & 35 & -30 & -3 & 20 \\
\hline 12 & Chemicals & -0.1 & -0.4 & 0.1 & -0.2 & -0.1 & 0.5 & 2.5 & 112 & 63 & 39 & -12 & -6 & 29 \\
\hline 13 & Oil refining & -0.9 & -0.4 & 0.0 & -0.2 & -0.1 & -0.1 & 2.7 & 47 & 45 & 28 & -12 & -5 & -9 \\
\hline 14 & Non-metals & 0.6 & 0.1 & 0.0 & -0.1 & -0.2 & 0.7 & 1.7 & 198 & 122 & 30 & -6 & -15 & 67 \\
\hline 15 & Metals & 0.1 & 0.2 & 0.5 & -0.6 & -0.3 & 0.3 & 3.1 & 132 & 93 & 69 & -31 & -13 & 15 \\
\hline 16 & Machinery & -0.7 & 0.1 & 0.0 & -0.8 & -0.3 & 0.4 & 2.4 & 60 & 85 & 28 & -57 & -23 & 28 \\
\hline 17 & Transport equipment & -0.2 & 0.3 & 0.1 & -0.6 & -0.1 & 0.2 & 1.3 & 78 & 118 & 39 & -88 & -10 & 19 \\
\hline 18 & Other manufactures & -0.1 & -0.3 & 0.0 & 0.0 & 0.1 & 0.2 & 0.7 & 102 & 20 & 24 & 7 & 18 & 34 \\
\hline 19 & Construction & 1.8 & 1.6 & 0.0 & 0.0 & 0.0 & 0.2 & 6.2 & 187 & 177 & 5 & -1 & 0 & 5 \\
\hline 20 & Public utilities & 0.4 & -0.3 & 0.0 & -0.1 & -0.1 & 0.9 & 2.7 & 157 & 75 & 39 & -4 & -3 & 51 \\
\hline 21 & Commerce, restaurants and hotels & 3.4 & 3.3 & 0.3 & -0.2 & 0.1 & -0.1 & 12.2 & 183 & 159 & 26 & -2 & 1 & -2 \\
\hline 22 & Finance & 0.7 & 0.7 & 0.0 & 0.0 & 0.0 & 0.0 & 1.5 & 217 & 193 & 27 & -2 & 0 & -1 \\
\hline 23 & Business services/real estate & 2.4 & -1.0 & 0.0 & -0.2 & 0.0 & 3.5 & 7.5 & 192 & 98 & 22 & -3 & 1 & 73 \\
\hline 24 & Transport & 1.0 & 0.0 & 0.1 & -0.1 & 0.0 & 1.0 & 6.9 & 155 & 83 & 50 & -2 & 1 & 22 \\
\hline 25 & Communications & 1.4 & 1.1 & 0.1 & 0.0 & 0.0 & 0.3 & 0.9 & 483 & 373 & 53 & -3 & -2 & 62 \\
\hline 26 & Public administration & -1.9 & -1.9 & 0.0 & 0.0 & 0.0 & 0.0 & 4.1 & 20 & 19 & 0 & 0 & 0 & 1 \\
\hline 27 & Education/health & -1.6 & -1.7 & 0.0 & 0.0 & 0.0 & 0.1 & 4.5 & 44 & 41 & 0 & 0 & 0 & 3 \\
\hline 28 & Other services & 0.0 & -0.6 & 0.0 & 0.0 & 0.0 & 0.6 & 1.6 & 124 & 52 & 7 & -1 & 5 & 61 \\
\hline \multirow[t]{3}{*}{ I } & Primary sector (1-4) & -3.1 & -1.5 & -1.0 & -0.3 & -1.2 & 0.9 & 19.4 & 86 & 25 & 66 & -2 & -10 & 7 \\
\hline & Non-mining (1) & -1.6 & -1.6 & -0.6 & -0.1 & -0.4 & 1.0 & 7.8 & 75 & 40 & 26 & -2 & -8 & 19 \\
\hline & Mining (2-4) & -1.5 & 0.1 & -0.5 & -0.2 & -0.9 & -0.1 & 11.6 & 94 & 16 & 93 & -3 & -11 & -1 \\
\hline \multirow[t]{3}{*}{ II } & Secondary sector $(5-18)^{b}$ & -2.8 & -3.4 & 0.4 & -3.4 & -1.5 & 5.2 & 38.7 & 105 & 77 & 27 & -14 & -6 & 20 \\
\hline & Light industry (5-10) & -3.2 & -4.3 & -0.4 & -0.8 & -0.5 & 2.9 & 17.8 & 82 & 43 & 25 & -6 & -5 & 24 \\
\hline & Heavy industry (11-19) & -1.5 & -0.8 & 0.8 & -2.6 & -0.9 & 2.1 & 14.8 & 99 & 77 & 39 & -29 & -10 & 22 \\
\hline \multirow[t]{2}{*}{ III } & Tertiary sector (20-28) & 5.9 & -0.5 & 0.4 & -0.6 & 0.1 & 6.4 & 41.9 & 153 & 106 & 25 & -2 & 1 & 23 \\
\hline & Total/average $^{\mathrm{c}}$ & 0.0 & -5.4 & -0.3 & -4.3 & -2.6 & 12.5 & 100.0 & 121 & 79 & 34 & -7 & -4 & 19 \\
\hline
\end{tabular}

Source: Prepared by the author on the basis of data from Banco Central de Chile (1993 and 2001a).

${ }^{\mathrm{a}}$ BP $\quad$ Basic prices.

$\delta \mathrm{X} / \mathrm{X}:$ : Change in share of gross output $(=\Delta \mathrm{S})$ (percentage points).

$\Delta \mathrm{X} / \mathrm{X}$ : Gross output growth rate $(\%)$.

FDE : Final demand expansion (percentage points).

EDE : Export demand expansion (percentage points).

ISF : Import substitution of final goods (percentage points).

ISW : Import substitution of intermediate goods (percentage points).

IOC : Change in input-output coefficients (percentage points).

S86 : Share of gross output in $1986(\%)$.

b The secondary sector (manufactures) includes construction.

${ }^{\mathrm{c}}$ Figures in bold type are totals; figures in italics are weighted averages. 
this fall was textiles, which showed negative growth rates over the period, and the food industry, whose growth rate was well below the averages for both the secondary sector and the economy as a whole. In heavy industry, the growth rates were all very positive, although mostly below the average for the economy. The main branches which lost shares were oil refining and machinery, but also chemicals, transport equipment and other manufactures. In contrast, non-metal and metal industries saw above-average growth rates with slight increases in their share of total gross output. Construction continued its upward trend with a growth rate well above the average for the period, increasing its share by 1.8 percentage points.

The factors contributing positively to growth rates were domestic demand and exports, but also direct intermediation, especially for the clothing, paper and printing, non-metal and machinery industries. In turn, the factor with a negative contribution to growth was import substitution ${ }^{11}$ of both final and intermediate goods, especially for the rubber, metal, machinery and transport equipment industries. There was apparently less domestic capacity to produce these goods, and therefore more import penetration. From the viewpoint of changes in output shares, the lower-than-average growth rates for most industries in this sector translated into falls in their shares over the period. All the constituent factors, except for intermediation (IOC) and, to a lesser degree, export expansion (EDE), contributed to this result. Except for metal-working industries, the contribution of export expansion to the share of the secondary sector was stagnant or negative. In simple terms, this means that the contribution of exports to growth rates, even if positive, was below the average for the whole economy. For the construction sector, there was a continuous upward trend in its share, so that it represented nearly $8 \%$ of total gross output in 1996. As expected, this increase was mostly due to domestic demand expansion, but also to direct intermediation to some extent.

In short, the first point to note is that the share of the heavy-industry sector underwent a relative, rather than absolute, decline, especially in industries such as oil refining, machinery, transport equipment and other manufacturing, although there was a slight rise in metal and non-metal industries. Second, although the declines are mostly attributable to overall import

${ }^{11}$ For the way in which the contribution of import substitution was calculated here, see note 8 . penetration, there was a considerable contribution from direct intermediation, which prevented the decline from being larger. There was also a small positive contribution from export expansion. Third, the lightindustry sector, as a whole, experienced a fall in its share of total output, despite high growth rates in most segments (except for textiles). Fourth, this fall was mostly due to import penetration and to weaker-thanaverage domestic demand and export expansion. Fifth, there was also a significant contribution from direct intermediation. This could mean that secondary sectors were better integrated with the rest of the economy than before, but it was probably mostly due to import penetration (see below). Sixth, in relative terms, there was generalized de-industrialization in both light and heavy industry. The former had shown a positive share trend in 1977-1986, which seems to have been largely undone over the 1986-1996 period. Lastly, the construction sector maintained an upward trend as a result of increased domestic demand.

From 1986 to 1996, in GDP terms, there was a significant decline in the share of manufacturing of about 4 percentage points, with a further percentage point lost by 2000 . This was because growth rates in the secondary industries were below the average for the whole economy, although they were not negative, except in the case of textiles. There are also some indications that this relative loss was not accompanied by productivity increases (Mujica, 1989; Ominami, 1991; Pizarro, Raczynski and Vial, 1996). For an economy that expects to achieve an export-led type of sustainable development, this could be worrying (Ffrench-Davis and Sáez, 1995; Albala-Bertrand, 1999a).

iii) The tertiary or services sector (table 1, lines 20 to 28 ). In the 1986-1996 period, in contrast to 1977 1986 , most of the constituent industries of this sector increased their shares in gross output significantly. The main industries accounting for these gains include commerce, restaurants and hotels, business services and real estate, transport, and communications. This was to be expected in any economy that had undergone high GDP growth over a particular period. However, this result is attributable not so much to the expansion in demand as to the large increase in the share of direct intermediation over the period, although this positive performance was partly counterbalanced by some import penetration of final goods. There was still some ground for concern, as both public administration and education and health were well below average growth rates, with significant falls in their shares of total gross output. 
To sum up, first the service sector's share increased impressively between 1986 and 1996, reversing a large fall in the previous period. Second, most of this outstanding performance was due to direct intermediation. Third, public administration and education/health showed very weak growth rates and a significant decline in shares, which could represent grounds for concern, as both are basic to a country's efficiency, i.e., to the coordination and productivity of the economy and society.

In GDP terms, the share of the services sector grew still further between 1986 and 1996, by around 3 percentage points. Commerce grew significantly, recovering from its fall in the previous period, and the same occurred with transport and, especially, communications. This was partly the result of the considerable entry of telecommunications companies over the period (Moguillansky, 1999). Finance remained more or less constant at the relatively high levels of 1986, with average growth rates close to those of GDP. The privatization and proliferation of pension funds may have contributed to this result, but the significant inflows of short-term capital were also a factor (Uthoff, 2001). In GDP terms, both public administration and education/health systematically lagged behind the average growth of the economy, not only between 1986 and 1996, but also in 2000 (Banco Central de Chile, various years).

Despite good growth rates over the period, it seems that the economy still did not favour the most technologically sophisticated sectors. Both light and heavy industry showed growth well below the average rate for the economy, losing ground in relation to services. Of the most technologically advanced industries, as classified by Wyckoff and Sakurai (1992), only metal and non-metal industries appear to have made some gains in output shares; rubber, machinery, transport equipment and other manufacturing all appear to have lagged behind. Finance, however, registered growth rates well above the average, which is normally considered a necessary complement to technological progress. ${ }^{12}$

In conclusion, despite the fall in the share of the secondary sector and the relative fall in the contribution of export expansion, the most interesting development over the period was the widespread increase in direct intermediation in the economy as a whole. This means that economic activities are

12 See also Albala-Bertrand (1999a). currently more integrated than ever before, but it may also mean that the economy is now more sensitive to partial shocks. In other words, a recessive shock in one sector may have stronger negative repercussions on the rest of the economy than in the past. Nonetheless, one should consider whether this increase in direct interdependence can be attributed to the interplay of domestic productive activities or to imported input penetration. For this reason, in the following paragraphs we will look at the issue of overall industrial interdependence in 1986-1996 and focus on direct and indirect backward and forward linkages.

\section{Structural changes in industrial interdependence}

The level and quality of industrial interdependence or linkages have much to do with development. Increased use of efficient inputs is associated with an increasingly complex economic system, that is, one in which production involves more cycles of intermediation or interdependence, as in the developed countries. There is also a positive correlation between linkages and final output (table 2). In some industries, apparently, an increase in intermediate linkages is followed by an increase in their final output, especially for manufactured exports and heavy or more sophisticated manufactures (Chenery and Syrquin, 1986).

Table 2 shows the rates of change (or growth rates) of backward linkages $(\triangle B L / B L)$, and forward linkages $(\triangle F L / F L)$ for the 1986-1996 period, decomposed into domestic (DOM) and imported (IMP) contributions, both in constant 1986 basic prices.

\section{a) Backward linkages (BL)}

By way of illustration, in the backward linkage section of table 2, under the heading "BL86" in the left-hand section, the value 2.1 for copper means that to produce one unit of copper (with a constant value equivalent to one peso) for final demand, a total of 2.1 units of direct and indirect intermediate-inputs are needed. The normalized value of $B L$ for the same year and sector, under the heading "NBL86", shows a number smaller than one, meaning that the backward linkages of the copper industry are below the average for the economy, which is to be expected as this is a "demand enclave", i.e., it generates little demand for inputs from other sectors. That value also shows average homogeneity, as it has an approximately average coefficient of variation. In 1996, the main leading or pulling sectors were mainly food and textiles, together 
TABLE 2

Chile: Growth rates of backward and forward linkages, by production activity and sector, between 1986 and $1996^{a}$

(Basic prices in constant 1986 pesos)

\begin{tabular}{|c|c|c|c|c|c|c|c|c|c|c|c|c|c|c|c|}
\hline \multirow{2}{*}{\multicolumn{2}{|c|}{ Production activity and sector }} & \multicolumn{7}{|c|}{ Backward linkages } & \multicolumn{7}{|c|}{ Forward linkages } \\
\hline & & $\Delta \mathrm{BL} / \mathrm{BL}(86)$ & DOM & IMP & BL86 & NBL96 & CV96 & SFD86 & $\Delta \mathrm{FL} / \mathrm{FL}(86)$ & DOM & IMP & FL86 & NFL96 & CV96 & SV86 \\
\hline 1 & Non-mining primary & 23 & 13 & 9 & 1.9 & 0.95 & 2.5 & 5 & 15 & 6 & 9 & 2.0 & 0.52 & 3.0 & 8 \\
\hline 2 & Copper & 3 & -3 & 6 & 2.1 & 0.88 & 2.7 & 9 & -1 & -3 & 2 & 1.2 & 0.27 & 4.9 & 5 \\
\hline 3 & Fuels & 90 & 32 & 58 & 2.1 & 1.62 & 2.2 & 0 & 545 & -89 & 633 & 7.7 & 11.19 & 1.4 & 1 \\
\hline 4 & Other minerals & 5 & 0 & 5 & 1.4 & 0.57 & 3.6 & 5 & 2 & -3 & 5 & 1.4 & 0.33 & 3.5 & 5 \\
\hline 5 & Food & 40 & 24 & 16 & 2.6 & 1.47 & 2.1 & 13 & 28 & 19 & 9 & 1.4 & 0.41 & 3.9 & 5 \\
\hline 6 & Textiles & 97 & 36 & 61 & 2.4 & 1.86 & 2.2 & 1 & 134 & 52 & 83 & 2.4 & 1.27 & 1.9 & 2 \\
\hline 7 & Clothing & -4 & -15 & 11 & 2.6 & 0.99 & 2.3 & 2 & 80 & 46 & 34 & 1.2 & 0.47 & 2.7 & 1 \\
\hline 8 & Lumber/wood & 48 & 37 & 11 & 2.1 & 1.23 & 2.0 & 2 & 16 & 4 & 12 & 2.1 & 0.54 & 2.5 & 2 \\
\hline 9 & Paper/printing & -2 & -7 & 5 & 2.1 & 0.83 & 2.5 & 1 & 44 & 20 & 24 & 2.2 & 0.69 & 1.8 & 1 \\
\hline 10 & Leather & -40 & -37 & -3 & 1.9 & 0.45 & 4.7 & 0 & 33 & 16 & 17 & 1.7 & 0.52 & 2.2 & 0 \\
\hline 11 & Rubber & 41 & 18 & 23 & 1.8 & 1.02 & 2.4 & 1 & 82 & 23 & 58 & 2.5 & 1.04 & 1.6 & 1 \\
\hline 12 & Chemicals & 8 & 1 & 6 & 2.2 & 0.95 & 2.9 & 2 & 30 & 6 & 25 & 4.1 & 1.20 & 1.4 & 3 \\
\hline 13 & Oil refining & 61 & -1 & 62 & 2.9 & 1.87 & 2.0 & 1 & 30 & -19 & 49 & 3.3 & 0.95 & 1.7 & 3 \\
\hline 14 & Non-metals & 23 & 5 & 19 & 2.1 & 1.05 & 2.3 & 0 & 17 & -1 & 18 & 2.8 & 0.74 & 2.1 & 2 \\
\hline 15 & Metals & $\mathbf{0}$ & -11 & 11 & 2.1 & 0.83 & 3.1 & 2 & 8 & -25 & 33 & 3.1 & 0.76 & 2.1 & 3 \\
\hline 16 & Machinery & 24 & 6 & 18 & 1.4 & 0.72 & 3.3 & 2 & 79 & 7 & 72 & 2.7 & 1.09 & 1.4 & 3 \\
\hline 17 & Transport equipment & 30 & 8 & 22 & 1.6 & 0.82 & 3.2 & 1 & 60 & 7 & 53 & 2.6 & 0.92 & 1.8 & 2 \\
\hline 18 & Other manufactures & 19 & 3 & 16 & 2.2 & 1.04 & 2.1 & 1 & 55 & 33 & 22 & 2.0 & 0.71 & 1.7 & 1 \\
\hline 19 & Construction & 31 & 16 & 15 & 2.1 & 1.08 & 1.9 & 8 & -3 & -12 & 9 & 1.4 & 0.30 & 3.9 & 5 \\
\hline 20 & Public utilities & 37 & 13 & 24 & 1.9 & 1.06 & 3.0 & 1 & 19 & -9 & 28 & 2.6 & 0.69 & 2.6 & 2 \\
\hline 21 & Commerce, restaurants and hotels & 19 & 10 & 9 & 1.8 & 0.83 & 2.7 & 13 & -7 & -20 & 13 & 1.8 & 0.37 & 3.4 & 13 \\
\hline 22 & Finance & 23 & 17 & 6 & 1.9 & 0.93 & 2.7 & 1 & -12 & -32 & 20 & 2.3 & 0.45 & 3.1 & 1 \\
\hline 23 & Business services/real estate & 15 & 9 & 6 & 1.4 & 0.64 & 3.5 & 7 & 31 & 1 & 30 & 2.0 & 0.59 & 2.1 & 10 \\
\hline 24 & Transport & 17 & 4 & 13 & 2.2 & 1.02 & 2.5 & 6 & 14 & -23 & 38 & 2.2 & 0.57 & 2.6 & 7 \\
\hline 25 & Communications & 16 & 17 & 0 & 1.4 & 0.67 & 3.6 & 1 & -11 & -27 & 15 & 2.2 & 0.44 & 3.1 & 1 \\
\hline 26 & Public administration & 44 & 31 & 14 & 1.8 & 1.01 & 2.0 & 7 & 1 & 1 & 0 & 1.0 & 0.23 & 5.1 & 5 \\
\hline 27 & Education/health & 34 & 25 & 9 & 1.4 & 0.77 & 2.7 & 7 & 4 & 2 & 1 & 1.0 & 0.24 & 4.9 & 6 \\
\hline 28 & Other services & 23 & 14 & 9 & 1.7 & 0.85 & 2.5 & 2 & 77 & 70 & 7 & 1.3 & 0.50 & 2.4 & 2 \\
\hline I. & Primary sector (1-4) & 9 & 2 & 7 & 1.9 & 1.01 & 2.9 & 19 & 41 & -5 & 46 & 2.0 & 3.08 & 3.9 & 20 \\
\hline II. & Manufactures: Light (5-10) & 36 & 19 & 17 & 2.5 & 1.14 & 2.4 & 20 & 46 & 23 & 23 & 1.8 & 0.65 & 3.0 & 12 \\
\hline & Heavy (11-18) & 23 & 2 & 21 & 2.0 & 1.04 & 2.9 & 10 & 41 & -3 & 43 & 3.1 & 0.92 & 1.7 & 16 \\
\hline & Construction $(19)^{\mathrm{b}}$ & 31 & 16 & 15 & 2.1 & 1.08 & 1.9 & 8 & -3 & -12 & 9 & 1.4 & 0.30 & 3.9 & 5 \\
\hline III. & Services $(20-28)$ & 25 & 15 & 10 & 1.7 & 0.87 & 2.8 & 44 & 10 & -8 & 18 & 1.8 & 0.45 & 3.2 & 47 \\
\hline & Average $^{c}$ & 25 & 12 & 12 & 2.0 & 1.00 & 2.6 & 100 & 25 & -3 & 28 & 2.0 & 1.00 & 2.9 & 100 \\
\hline
\end{tabular}

Source: Prepared by the author on the basis of data from Banco Central de Chile (1993 and $2001 \mathrm{a})$.

\footnotetext{
${ }^{\mathrm{a}}$ BP : Basic prices.

$\Delta \quad$ : Variation.

DOM : Domestic (percentage points).

IMP : Imported (percentage points).

BL : Backward linkages (pesos).

NBL : Normalized backward linkages (pesos).

CV96 : Coefficient of variation in 1996 (pesos).

SFD : Share in domestic final demand (percentage points).

FL : Forward linkages (pesos).

NFL : Normalized forward linkages (pesos).

CV96 : Coefficient of variation in 1996 (pesos).

SV : Share in value added (percentage points).

b The secondary sector (manufactures) includes construction.

c Sum of SFD86 and Sv86.
} 
with fuels and oil refining, although the latter two started from a very low base, as their share of GDP in 1986 was small or negligible. The main lagging sectors are other minerals, leather, machinery, business services and real estate, communications, and education and health. Given the importance of imported inputs in most of the leading industries, especially oil refining, and the key role of such inputs in most other sectors, this could have negative consequences for the country's productive integration.

In 1986-1996, following a trend similar to that of the 1977-1986 period, backward linkages increased on average by a further $25 \%$. This means that when the economy produced 100 units of final domestic output, this generated on average nearly 25 more units of backward intermediate demand in 1996 than in 1986. This was due in particular to increases in the backward linkages of construction and light industry. However, a good deal of the increase came from imported intermediation, especially in heavy industry. On the whole, imported and domestic intermediates appear to share the increase in equal terms, although, in heavy industry, this increase is led by imported, rather than domestic, materials. This was also the trend in the previous period, but it appears less intense in 19861996. This may have consequences for both foreign vulnerability and endogenous technological development (Albala-Bertrand, 1999b).

At a disaggregated level, we can observe that, firstly, for primary industries, it seems that the rises in backward linkages are mostly due to fuels and secondarily to non-mining primary industries. In the case of fuels, there was a significant increase in both domestic and imported intermediation, but generally it was the latter which carried most weight. Copper -in contrast with the $1977-1986$ period-showed a very small increase of $3 \%$, due to a fall in domestic intermediation by three percentage points and a rise in imported intermediation by six percentage points.

Secondly, the backward linkages of the light industrial sector, which had shown a significant fall in the 1977-1986 period, registered a sizeable increase in 1986-1996, mainly due to food and textiles. Clothing, paper and printing and leather, however, showed declines due entirely to significant falls in domestic intermediation.

Thirdly, heavy industries showed a significant average increase in backward linkages, but almost completely due to imported intermediation. The strongest positive effects came from rubber, oil refining, transport equipment and machinery, with only a minor contribution from domestic sources. Metal industries, for their part, showed zero growth, due entirely to the substitution of imported for domestic inputs by 11 percentage points. Construction showed more balanced intermediation than the other sectors.

Lastly, the tertiary sector showed an increase in backward linkages, with a more important contribution from domestic than from foreign sources, except in the case of transport.

The main point here is that although imported intermediation represented $50 \%$ of the total change, this proportion rose to nearly $90 \%$ in the most technologically sophisticated part of the economy. All the constituent industries of the heavy industrial sector were strongly affected by this imported input penetration. This may conspire against endogenous sustainability, but it should preserve the competitiveness of the industries that use more sophisticated imported inputs. The open Chilean economy, then, is moving towards greater reliance on imported inputs for its normal productive requirements. In the 1977-1986 period there was a decline in domestic backward intermediation, which was then considered as reflecting a process of generalized disintermediation (see Albala-Bertrand, 1999b), but this appears to have been reversed in most industrial activities, except heavy industry.

Quite apart from its implications for employment, the increase in imported backward linkages can only directly benefit foreign exporters and domestic importers, and therefore has little or no positive effect on endogenous productive interdependence between industries. From this point of view, the potentially positive results of an increase in the demand for inputs would have an impact both outside the economy, on foreign exporters, and on the trade of domestic importers, but they would be of little help to domestic productive manufacturing. This could be insufficient for the development of domestic manufacturing. ${ }^{13}$

\section{b) Forward linkages (FL)}

In similar fashion to what occurs with backward linkages, an economy with a growing and dynamic industrial base would be expected to have a broad, strong supply of domestic intermediate goods. This of course does not preclude firms increasing their output to satisfy both final and export demands provided that,

\footnotetext{
13 As in the extreme case of an assembly-line manufacturing economy which only assembles parts produced abroad but purchases those parts from domestic importers belonging to other sectors.
} 
other things being equal, they do not do so on a widespread and intensive basis at the expense of domestic input supply (Albala-Bertrand, 1999b). During the period studied, total forward linkages grew at the same rate as backward linkages, but the whole of this increase was due to growth in the domestic supply of imported inputs, which also displaced three percentage points of the existing supply of inputs of domestic origin. If we exclude the two industries (fuels and textiles) which showed the highest variation in forward linkages, the increase is more moderate, but keeps the same pattern. There was a generalized fall in forward intermediation of domestic origin, so the growth in input supply was due to an increase in the supply of imported inputs, at the expense of domestic supply. In other words, increases in value added created opportunities for suppliers of imported inputs, rather than domestic producers.

This may mean that, in practice, a fair number of domestic producers gave up the possibility of supplying the internal market with domestic products, in favour of marketing imports. This trend had already been apparent in the 1977-1986 period, when almost all the industries considered showed negative intermediation from domestic sources. In 1986-1996 that trend continued to some extent: for a good number of sectors the change in domestic intermediation was negative, while that of imported input supply was positive. Except for light industry, all other sectors showed negative contributions from domestic intermediation. The worst-affected sectors were fuels, metals, finance, transport and communications. This indicated both a consolidation of the domestic disintermediation seen in the previous period and a further departure from the type of domestic integrative process experienced in the Taiwanese economy and the Republic of Korea (Albala-Bertrand, 1999b). As with backward linkages, this represents a generalized process of domestic disintermediation.
A general conclusion for both backward and forward linkages is that this intense import penetration can have mixed consequences for the development of a growing economy. On the one hand, the economy can select the most efficient foreign sources for its input requirements and use inputs that are more technologically sophisticated, which may be beneficial. On the other hand, the economy may become more vulnerable to external fluctuations, which can lead to increased instability (Damill, Fanelli and Frenkel, 1996; Chang and Grabel, 2004). No less importantly, the economy may lose an important degree of efficiency by not exploiting the domestic synchronization of the necessary inputs and their specifications, thus stifling the potential for domestic technological development. The avoidance of this anomaly, associated with deliberate input policies, proved to be one of the main engines of efficient coordination between the needs of industry and supply from domestic producers in the Taiwanese and Korean economies, which also helped to improve domestic technological sophistication. ${ }^{14}$ This factor appears to have been further eroded in Chile over the 1986-1996 period, and also, in general, up to 2000 (Banco Central de Chile, various years), which may have had negative consequences for sustained, technologically advanced growth. In other words, in order for Chile to take full advantage of its potential for efficiency and technological development -as the Taiwanese economy and the Republic of Korea did- access to varied foreign input sources must be balanced with the nurturing of sources of domestic inputs. Given that there are costs and benefits involved in liberalization and regulation strategies, policymakers need to strike a delicate balance between the two in order to ensure, or at least not suffocate, the endogenous sustainability of increased domestic technological sophistication and the efficiency associated with inter-industry coordination.

\footnotetext{
${ }^{14}$ See Kubo, de Melo and others (1986); Wyckoff and Sakurai (1992); Chang (1996); Stiglitz (1996); Albala-Bertrand (1999b); Islam and Choudhury (2000); Chang and Grabel (2004).
}

CHANGES IN CHILE'S PRODUCTION STRUCTURE, 1986-1996: OUTPUT AND INDUSTRIAL INTERDEPENDENCE • JOSÉ MIGUEL ALBALA-BERTRAND 


\section{IV}

\section{Conclusions}

Up to 1986, Chile appeared to have departed from, or at least not moved towards, the kind of successful industrial structure that the Taiwanese economy and the Republic of Korea had achieved some 15 to 20 years after the beginning of their rapid drive to development (Albala-Bertrand, 1999a and 1999b). Almost 20 years after its fully-fledged economic liberalization began, the structure of the Chilean economy does not appear to have closed the gap with the two Asian countries. If anything, it seems to have fallen further behind, especially in the area of endogenous technological sophistication. This may have long-term consequences in terms of technological development, sustainable development and the overall stability of the economy.

ECLAC data show that, as late as 1996, the share of manufacturing in GDP was around $20 \%$ and that of heavy industry around $2 \%$. Likewise, the share of exports in GDP was around $25 \%$, but that of manufacturing exports was only $3 \%$, while the share of heavy manufacturing in GDP remained negligible. This pattern continued until
2000 and does not seem to have changed significantly to date (ECLAC, various years). Given that the Chilean economy slowed significantly or was in recession after 1996, with an average growth rate around half of that achieved in the previous 10 years, it is unlikely that domestic intermediation has increased or that sophisticated manufacturing has taken hold. Furthermore, these insufficiencies can have negative impacts on income distribution, anti-poverty measures, and overall well-being, or at least delay improvements in those areas. ${ }^{15}$

Therefore, other successes notwithstanding, the economic development model adopted by Chile still does not appear to favour endogenous interdependence, especially of the type led by technologically sophisticated sectors. Neither does it appear to be leading towards the type of exports that can sustain and promote dynamic export-oriented industrial development. In other words, the economy still appears to be relatively weak as a basis for a sustainable increase in economic and technological sophistication.

\section{Bibliography}

Achurra, M. (1995): La experiencia de un nuevo producto de exportación: los salmones, in P. Meller and R. Sáez (eds.), Auge exportador chileno: lecciones y desafios futuros, Santiago, Chile, Dolmen Ediciones.

Agosin, M. (1997): Export Performance in Chile: Lessons for Africa, Wider Working Papers, No. 144, Helsinki, World Institute for Development Economics Research.

Albala-Bertrand, J.M. (1996): Structural Change in Chile: 19601990. An Input-output Approach, Working Paper Series, No. 354, London, University of London.

(1999a): Structural change in Chile: 1960-1990, Economic Systems Research, vol. 11, No. 3, London, Routledge.

(1999b): Industrial interdependence change in Chile: 1960-1990. A comparison with Taiwan and South Korea, International Review of Applied Economics, vol. 13, No. 2, London, Routledge.

Banco Central de Chile (1993): Matriz de insumo-producto para la economía chilena 1986, Santiago, Chile. (2001a): Matriz de insumo-producto para la economía chilena 1996, Santiago, Chile.

(2001b): Cuentas nacionales, 1999, Santiago, Chile. (various years): Boletín mensual, Santiago, Chile.

Bulmer-Thomas, V. (1982): Input-Output Analysis in Developing Countries, New York, John Wiley.

Ciaschini, M. (ed.) (1988): Input-Output Analysis: Current Developments, London, Chapman and Hall.
Chang, H.J. (1996): The Political Economy of Industrial Policy, London, Macmillan.

Chang, H.J. and I. Grabel (2004): Reclaiming Development, London, Zed Books.

Chenery, H. (1960): Patterns of industrial growth, American Economic Review, vol. 50, No. 4, Nashville, Tennessee, American Economic Association.

Chenery, H. and M. Syrquin (1986): Typical patterns of transformation, in H. Chenery, S. Robinson and M. Syrquin (eds.), Industrialization and Growth, New York, Oxford University Press.

\footnotetext{
15 The figures on poverty and income distribution for the Taiwanese economyand the Republic of Korea are among the best in the world (Islam and Choudhury, 2000; Sundrum, 1990). In Chile, almost two decades of structural change left unprecedented levels of both poverty and inequalities (AlbalaBertrand, 1996). Although poverty has been reduced since the return to democracy in 1990, income distribution has continued to worsen; the inequalities inherited from the dictatorship have remained. Chile is now the country with the ninth worst income distribution in the world (UNDP 2004; MIDEPLAN, 2000; Pizarro, Raczynski and Vial, 1996).
} 
Damill, M., J.M. Fanelli and R. Frenkel (1996): De México a México: el desempeño de América Latina en los noventa, Desarrollo económico, vol. 36, special issue, Buenos Aires, Institute of Economic and Social Development (IDES).

Dervis, K., J. de Melo and S. Robinson (1982): General Equilibrium Models for Development Policy, New York, Cambridge University Press.

Dietzenbacher, E. and B. Los (1998): Structural decomposition techniques: sense and sensitivity, Economic Systems Research, vol. 10, No. 4, London, Routledge.

ECLAC (Economic Commission for Latin America and the Caribbean) (various years): Statistical Yearbook for Latin America and the Caribbean, Santiago, Chile.

Ffrench-Davis, R. and B. Stallings (eds.) (2001): Reformas, crecimiento y políticas sociales en Chile desde 1973, Santiago, Chile, ECLAC/LOM Ediciones.

Ffrench-Davis, R. and R. Sáez (1995): Comercio y desarrollo industrial en Chile, Colección Estudios de CIEPLAN, No. 41, Santiago, Chile, December.

Hirschman, A. (1958): The Strategy of Economic Development, New Haven, Yale University Press.

(1977): Enfoque generalizado del desarrollo por medio de enlaces, con referencia general a los productos básicos, El trimestre económico, vol. 44(1), No. 173, Mexico City, Fondo de Cultura Económica, JanuaryMarch.

Islam, I. and A. Choudhury (2000): The political economy of East Asia. Post-crisis debates, Oxford, Oxford University Press.

Krueger, A. (1990): Government failures in development, Journal of Economic Perspectives, vol. 4, No. 3, Nashville, Tennessee, American Economic Association.

Kubo, Y., J. de Melo and others (1986): Interdependence and industrial structure, in $\mathrm{H}$. Chenery, S. Robinson and $\mathrm{M}$. Syrquin (eds.), Industrialization and Growth, New York, Oxford University Press.

Lall, S. (1996): Learning from the Asian Tigers: Studies in Technological and Industrial Policy, London, Macmillan Press.

(1997): Selective policies for export promotion: lesson from Asian Tigers, Research for Action, No. 43, Helsinki, World Institute for Development Economics Research.

MIDEPLAN (Ministry of Planning and Cooperation) (2000): Encuesta CASEN 2000, Santiago, Chile.

Moguillansky, G. (1999): La inversión en Chile: ¿el fin de un ciclo en expansión?, Santiago, Chile, Eclac/Fondo de Cultura Económica.
Mujica, J. (1989): Deindustrialization in Chile, Boulder, Colorado, Westview.

Ominami, C. (1991): Deindustrialization and industrial restructuring in Latin America: the examples of Argentina, Brazil and Chile, in P. Meller (ed.), The Latin American Development Debate: Neostructuralism, Neomonetarism and Adjustment Processes, Boulder, Colorado, Westview.

Pizarro, C., D. Raczynski and J. Vial (eds.) (1996): Social and Economic Policies in Chile's Transition to Democracy, Santiago, Chile, Economic Research Corporation for Latin America (CIEPLAN).

Sakurai, N. (1990): Methodology of Multisectoral Growth Decomposition Models: A Survey and Extensions, $O E C D$ Discussion Paper, No. 1, Paris, Organisation for Economic Co-operation and Development (OECD).

Stiglitz, J. (1996): Some lessons from the East Asian miracle, The World Bank Research Observer, vol. 11, No. 2, Washington, D.C., World Bank, August.

(1998): More Instruments and Broader Goals: Moving toward the Post-Washington Consensus, Helsinki, United Nations University/World Institute for Development Economics Research.

Stiglitz, J. and M. Uy (1996): Financial markets, public policy and the East Asian miracle, The World Bank Research Observer, vol. 11, No. 2, Washington, D.C., World Bank.

Sundrum, R.M. (1990): Income Distribution in Less Developed Countries, London, Routledge.

Syrquin, M. (1992): Linkages and the strategy of development, in S. Teitel (ed.), Towards a New Development Strategy for Latin America, Washington, D.C, Inter-American Development Bank (IDB).

UNDP (United Nations Development Programme) (2004): Human Development Report 2004, New York.

Uthoff, A. (2001): La reforma del sistema de pensiones y su impacto en el mercado de capitales, in R. Ffrench-Davis and B. Stallings (eds.), Reformas, crecimiento y políticas sociales en Chile desde 1973, Santiago, Chile, ECLAC/LOM Ediciones.

Wade, R. (1990): Governing the Market: Economic Theory and the Role of the Government in East Asian Industrialization, Princeton, Princeton University Press.

Williamson, J. (ed.) (1990): Latin American Adjustment. How Much Has Happened?, Washington, D.C., Institute for International Economics.

Wyckoff, A. and N. Sakurai (1992): Structural Change and Industrial Performance, Paris, Organisation for Economic Co-operation and Development (OECD). 